\title{
David Evans, Rhythm, Illusion and the Poetic Idea. Baudelaire, Rimbaud, Mallarmé
}

\section{Alessandra Marangoni}

\section{(2) OpenEdition}

1 Journals

\section{Edizione digitale}

URL: https://journals.openedition.org/studifrancesi/26661

DOI: $10.4000 /$ studifrancesi.26661

ISSN: 2421-5856

\section{Editore}

Rosenberg \& Sellier

\section{Edizione cartacea}

Data di pubblicazione: 1 avril 2007

Paginazione: 205

ISSN: 0039-2944

\section{Notizia bibliografica digitale}

Alessandra Marangoni, «David Evans, Rhythm, Illusion and the Poetic Idea. Baudelaire, Rimbaud, Mallarmé», Studi Francesi [Online], 151 (LI | I) | 2007, online dal 30 novembre 2015, consultato il 22 novembre 2021. URL: http://journals.openedition.org/studifrancesi/26661 ; DOI: https://doi.org/ 10.4000/studifrancesi.26661

Questo documento è stato generato automaticamente il 22 novembre 2021.

\section{(c)}

Studi Francesi è distribuita con Licenza Creative Commons Attribuzione - Non commerciale - Non opere derivate 4.0 Internazionale. 


\title{
David Evans, Rhythm, Illusion and the Poetic Idea. Baudelaire, Rimbaud, Mallarmé
}

\author{
Alessandra Marangoni
}

\section{NOTIZIA}

DAVID EVANS, Rhythm, Illusion and the Poetic Idea. Baudelaire, Rimbaud, Mallarmé, Amsterdam-New York, Rodopi, «Faux Titre» 254, 2004, pp. 356.

1 Libro consigliabile per l'informazione e la profondità di vedute di cui dà prova l'Autore nell'affrontare il tema e il trattamento del ritmo in tre "mostri sacri" della seconda metà dell'Ottocento: Baudelaire, Rimbaud, Mallarmé. Il ritmo quale suggello e privilegio del verso regolare (il ritmo impresso al verso come Dio è immanente alla Natura) è un'idea di Hugo e di Banville (di cui si veda il Petit Traité de poésie française), malgrado le vette toccate dalla prosa poetica di Chateaubriand. Lo sconvolgimento del tradizionale abbinamento ritmo-verso regolare si ha, in particolare, col poème en prose di Baudelaire, col verso libero delle Illuminations "Marine" e "Mouvement" e con Un Coup de dés. Apprezzabili le analisi delle perturbazioni del ritmo dell'alessandrino, tramite rejet e contre-rejet, nelle Fleurs du mal, di cui si tiene conto anche delle varianti. Condivisibile il Rimbaud aperto a una nuova e diversa «Beauté», più cacofonica che armonica. E poi Mallarmé - fautore di un ritmo mimetico dell'oggetto - tra sonetto, «refuge absolu de l'alexandrin», e il finale incoronamento del caso («le Hasard»). Insomma, col poème en prose Poesia e Ritmo devono trovare una nuova definizione indipendente dal verso; eppure l'idea di ritmo uscirà incolume dal naufragio del verso regolare, diventando un insopprimibile garante di unità. E l'autore avanza: l'impossibilità contemporanea di accettare l'idea di poesia senza fare ricorso a quella di ritmo è frutto di una mistificazione della poesia nata nella seconda metà dell'Ottocento, con i tre "padri" 
della modernità poetica, appunto Baudelaire, Rimbaud, Mallarmé. Scomparso Dio, rimane il suo garante: il ritmo. 